\title{
- 연구노트 -
}

\section{Macro 향 캡슐의 제조 및 향 성분의 저장 안정성}

\author{
차용준 $^{1} \cdot$ 김진현 $^{2} \cdot$ 유대웅 $^{1,2}$ \\ ${ }^{1}$ 창원대학표 식품영양학과 \\ 2창원대학표 시니어휴먼에콜로지협동과정
}

\section{Preparation of Macro Fragrance Capsule and Its Stability During Storage}

\author{
Yong-Jun $\mathrm{Cha}^{1}$, Jin Hyeon $\mathrm{Kim}^{2}$, and Daeung $\mathrm{Yu}^{1,2}$ \\ ${ }^{1}$ Department of Food and Nutrition and ${ }^{2}$ Department of Human Senior Ecology \\ Cooperative Course, Changwon National University
}

\begin{abstract}
Macro fragrance capsule composed alginic acid, and Tween 60 as wall materials and mixed herbal scents (lemongrass, rosemary, lavender, and cinnamon, 3:3:3:1 ratio, v/v) as core material was prepared in this study, and the stability of the flavor compounds in macro fragrance capsule during storage was analyzed. The moisture content during the storage of the fragrance capsule gradually decreased to 28 day of storage. In the flavor holding capacity, the amount of flavor was volatilized with storage times, and the reduction up to 10 days was significant $(P<0.05)$, and after that fluctuates, whereas the odor intensity of fragrance capsule decreased with storage times. A total of 56 compounds were identified, including terpenes (18), terpene alcohols (17), aldehydes and ketones (14), esters (6), and acid (1). The content of linalyl acetate was the most amount with 10,039.48 $\mu \mathrm{g}$, followed by linalool $(4,375.41 \mu \mathrm{g}),(E)$-citral $(4,246.77 \mu \mathrm{g}),(Z)$-citral $(3,347.88 \mu \mathrm{g})$, eucalyptol $(2,267.33 \mu \mathrm{g})$, camphor isomer $(2,266.45$ $\mu \mathrm{g})$, and $(E)$-cinnamaldehyde $(1,880.33 \mu \mathrm{g})$ in that order. The antimicrobial activity of mixed fragrances against four of food poisoning bacteria was proved until 20 day, which is with over $1,000 \mathrm{ppm}$ level.
\end{abstract}

Key words: macro capsule, sodium alginate, encapsulation, volatile flavor compounds, storage stability

\section{서 론}

캡슐화는 목적하는 물질에 영향을 줄 수 있는 빛, 산소, 수분 등의 외부 환경으로부터 향료 물질이나 영양성분 등과 같은 물질을 보호하여 손실을 줄이는 기술로써 향료, 제약 및 섬유산업에서 광범위하게 사용되어왔다(Gibbs 등, 1999). 식품산업에서는 산화 방지, 기능성 유지, 보존성 향상 및 이 취 차단 등의 목적으로 압출성형, 분무건조, 동결건조 및 에 멀젼 형태 등으로 다양하게 제조되었다(Gibbs 등, 1999; Heinzelmann과 Franke, 1999). 이때 핵물질(core material)을 보호하는 피복물질(wall material)로는 gum arabic, cyclodextrin 및 sodium alginate 등이 주로 사용되는데, 그 중 sodium alginate의 경우 피막 형성과 향기성분을 포집하 는 능력이 우수하고 에멀젼 형태로 제조하여 크기를 $\mathrm{mm}$ 단 위의 macro 캡슐로 제조할 수 있었다(Cho 등, 1999; Chan

Received 28 Jan 2021; Revised 2 Mar 2021; Accepted 2 Mar 2021 Corresponding author: Daeung Yu, Department of Food and Nutrition, Changwon National University, 20, Changwondaehak-ro, Uichang-gu, Changwon-si, Gyeongnam 51140, Korea,

E-mail: duyu@changwon.ac.kr,

Author information: Yong-Jun Cha (Professor), Jin Hyeon Kim (Graduate student), Daeung Yu (Professor)
등, 2011). 식품분야의 micro 또는 nano 캡슐은 액상식품의 분말화에 국한되어 주로 조미용으로 이용되는 것에 반해, macro 캡슐은 그 자체로 조직감과 같은 물성을 가지므로 식품소재뿐만 아니라 그 활용 범위가 매우 다양하게 적용될 것으로 기대된다(Yong 등, 2011; Surh와 Yang, 2019). 또 한, 핵물질이 향료인 경우 캡슐화에 의해 방출 속도를 조절 하여 장시간 향을 지속하게끔 할 수도 있었다(Reineccius, 1991; Tari와 Singhal, 2002).

허브는 라틴어의 허비(herba)에서 비롯된 단어로 요리용 이나 약용으로 사용할 수 있는 풀이나 관목을 가리키며 독특 한 풍미를 가져 식용으로도 사용된다(Lue와 Lee, 1998). 또한 허브 오일은 스트레스 해소, 방부, 항균작용, 노화방지 등과 같은 다양한 생리적 기능이 있으며 제품의 저장성과 안전성에 기여한다고 보고되었다(Marriott와 Robertson, 2009; Hill 등, 2013). 이러한 허브 오일을 나노 캡슐화했을 때 구강 병원성에 대한 항균 활성 및 저장 안정성이 향상되 었으며(Lee 등, 2020), 하나 이상의 허브 추출물을 사용했 을 때 시너지 효과로 더 높은 항균 활성이 있다고 하였다 (Soleimanpour 등, 2015; Cha 등, 2016a; Pei 등, 2009).

한편, 알긴산(alginic acid)은 미역, 다시마와 같은 갈조류 에서 추출되는 다당류로서 D-mannuronic $\operatorname{acid}(\mathrm{M})$ 와 Lguluronic $\operatorname{acid}(\mathrm{G})$ 가 $1,4-\mathrm{glycoside}$ 결합으로 연결되어있 
는데, 이러한 구조적 특성이 칼슘이온 $\left(\mathrm{Ca}^{2+}\right)$ 과 반응하면 2 가 양이온인 $\mathrm{Ca}^{2+}$ 가 음전하를 띤 알긴산 분자들과 가교하여 겔을 형성하게 한다(Woo 등, 2007). 알긴산은 인체에 무해 하며 경제적이고 캡슐 제조가 용이하며 수분흡수 능력 및 결착 능력 등의 다양한 특성을 가지고 있어 식품, 화장품, 제지 및 의약품 등의 여러 분야에서의 연구가 많이 보고되었 다(Cho 등, 2005). 알긴산의 식품 및 향기성분 포집에 대한 연구는 calcium alginate bead의 에센셜 오일 방출 제어능 력에 대한 연구(Lai 등, 2007), 감 calcium alginate bead 제조 및 그 특성 연구(Yong 등, 2011), 커피-calcium alginate bead 제조 및 특성에 관한 연구(Surh와 Yang, 2019) 가 보고되었으나, 이러한 연구들은 bead 제조 방법과 시간, 농도 등의 요인에 따른 품질 특성에만 국한되어 항기성분의 포집이나 향기성분의 유출 등에 관한 연구는 전혀 보고되지 않았다.

따라서 본 연구에서는 피복물질로 알긴산을 이용하고 핵 물질로는 다목적용으로 많이 활용되는 대표적인 허브향인 레몬그라스, 로즈마리, 라벤더 및 시나몬을 이용하여 macro 향 캡슐을 제조하고, 저장기간 동안 향 캡슐의 휘발성 향기 성분의 변화와 향 성분의 안정성을 분석하여 식품 제조 및 가공 분야의 기초자료로써 활용하고자 하였다.

\section{재료 및 방법}

\section{실험재료}

캡슐화에 사용된 sodium alginate는 Junsei Chemical Co., Ltd.(Tokyo, Japan), 염화칼슘은 대정화금(주)(Siheung, Korea), 허브향(레몬그라스, 로즈마리, 라벤더, 시나몬)은 (주)제이씨와이(Seongnam, Korea), Tween 60(polyoxyethelene sorbitan monosterate)은 (주)삼전화학(Seoul, Korea) 제품을 구입하여 사용하였다. 항균성 실험의 dimethyl sulfoxide(DMSO)는 Sigma-Aldrich(St. Louis, MO, USA) 에서, 액상배지는 Mueller-Hinton broth(Difco Co., Detroit, MI, USA)를 사용하였다. 병원성 미생물인 Bacillus subtilis(KCTC 1021), Staphylococcus aureus(KCTC 1916), Bacillus cereus(KCTC 1012), Escherichia coli (KCTC 1682)는 생물자원센터(Korean Collection for Type Culture, Daejeon, Korea)에서 분양받아 사용하였다.

\section{Macro 향 캡슐 제조}

시료의 제조조건은 예비실험을 거쳐 선정하였는데(Cha, 2020), 2\%(w/v) 알긴산용액 $100 \mathrm{~mL}(93.9 \%, \mathrm{v} / \mathrm{v})$, 혼합향 (레몬그라스:로즈마리:라벤더:시나몬을 3:3:3:1의 비율, $\mathrm{v} /$ v) $2.5 \mathrm{~mL}(2.3 \%, \mathrm{v} / \mathrm{v})$, Tween $604 \mathrm{~mL}(3.8 \%, \mathrm{v} / \mathrm{v})$ 와 사프 라닌 2 3방울을 넣고 균질기(Ultra-Turrax T25, IKALabortechnik, Staufen, Germany)로 9,500 rpm에서 10분 간 균질화시킨 다음 뷰렛을 이용하여 $1 \%(\mathrm{w} / \mathrm{v})$ 염화칼슘 용 액에 적하시켰다. 형성된 향 캡슐의 일정량을 상온에서 건조
시킨 후 최종제품으로 하였다. 사프라닌 색소는 캡슐이 잘 형성되는지 육안으로 확인하기 위해 첨가하였고 향 캡슐은 $\varnothing 4.0 \pm 1.0 \mathrm{~mm}, 0.03 \pm 0.01 \mathrm{~g}$ 의 크기로 제조하였다. 상단 입구를 부직포로 밀봉한 라운드형 플라스틱 용기 $(740 \mathrm{~mL}$, (주)조이라이프, Gimhae, Korea)에 염화칼슘(제습 목적, (주)조이라이프) $260 \mathrm{~g}$ 과 향 캡슐 $45 \mathrm{~g}$ 을 각각 넣고 상온 $\left(25 \sim 30^{\circ} \mathrm{C}\right)$ 에서 저장실험(33일)을 하였다.

\section{저장 중 향기성분의 solid phase microextraction(SPME) 분석}

향 캡슐의 저장기간에 향기성분의 추출 및 흡착은 $\mathrm{SPME}$ 법으로 분석하였고, 향 보유율은 최초 향기성분 총 함량에 대한 잔존 함량을 백분율 $(\%)$ 로 나타내었다. SPME 분석은 향 캡슐 시료 $1 \mathrm{~g}$ 을 $20 \mathrm{~mL}$ headspace glass vial(Supelco Inc., Bellefonte, PA, USA)에 넣은 다음 메탄올에 내부표 준물질 2,5-dimethylpyrazine(Sigma-Aldrich Co.)을 녹 인 $1 \mu \mathrm{L}(9.7 \mu \mathrm{g} / \mathrm{g})$ 를 넣은 후 밀봉하여 $45^{\circ} \mathrm{C}$ 에서 30 분간 magnetic bar로 교반하면서(6.5 rpm) polydimethylsiloxane/divinylbenzene(PDMS/DVB) fiber(0.65 $\mu \mathrm{m}$ coating thickness, Supelco Inc.)에 흡착시켰다. SPME법에 의한 휘발성 성분의 추출은 Cha 등(2016b)의 방법에 따라 실험 하였고 시료당 3 회 반복 실험하였다.

\section{향기성분의 $\mathrm{GC} / \mathrm{MSD}$ 분석 및 동정}

포집된 향기성분은 Perkin Elmer clarus 600T gas chromatography/mass selective detector(GC/MSD, Perkin Elmer Co., Fremont, CA, USA)에 주입하여 분석하였 다. 컬럼은 $\mathrm{DB}-\mathrm{WAX}^{\mathrm{TM}}$ capillary column(60 m length $\times$ $0.25 \mathrm{~mm}$ I.D $\times 0.25 \mu \mathrm{m}$ film thickness, J\&W Scientific, Folsom, CA, USA)을 사용하였다. 각 화합물은 표준품과의 retention indices(RI) 비교 및 NIST(National Institute of Standards and Technology) standard MS library da$\mathrm{ta}$ (Perkin Elmer Co.)로 동정하였으며, 동정된 휘발성 화합 물의 함량은 내부표준물질에 대한 상대적 면적비로 계산하 였다.

\section{수분함량 및 향 sniffing test 실험}

향 캡슐의 수분함량은 $\mathrm{AOAC}(1996)$ 의 방법에 따라 $105^{\circ} \mathrm{C}$ 의 drying oven에서 24 시간 건조 후 중량을 측정하 여 건조 전 시료의 중량에 대한 백분율 $(\%)$ 로 나타내었다.

향 강도의 sniffing test는 후각 인지능력이 우수한 실험 자 4명으로 대조구로 라벤더 에션셜 오일을 7점으로 두고, 이와 같은 향 강도의 상태를 7점, 보통이다 4점, 가장 약하다 를 1점으로 두고 반복 실험하였다.

\section{MIC법에 의한 미생물 항균성 실험}

혼합 향의 $\mathrm{MIC}$ (minimum inhibitory concentration)법을 측정하고자 $\mathrm{DMSO}$ 에 적정농도 $(1,000 \mu \mathrm{g} / \mathrm{mL}, 2,000 \mu \mathrm{g} /$ 
$\mathrm{mL}, 3,000 \mu \mathrm{g} / \mathrm{mL}, 4,000 \mu \mathrm{g} / \mathrm{mL}, 5,000 \mu \mathrm{g} / \mathrm{mL}, 6,000 \mu \mathrm{g} /$ $\mathrm{mL}, 7,000 \mu \mathrm{g} / \mathrm{mL}, 8,000 \mu \mathrm{g} / \mathrm{mL}, 9,000 \mu \mathrm{g} / \mathrm{mL}$ )로 희석한

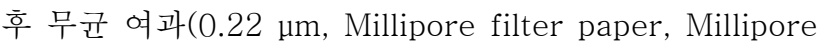
Corporation, Bedford, MA, USA)하였다. 멸균된 cap tube 에 Muller-Hinton broth $1 \mathrm{~mL}$, 병원성 미생물(B. subtilis, S. aureus, B. cereus, E. coli) $1 \mathrm{~mL}$, 여과한 혼합 향 0.5 $\mathrm{mL}$ 를 무균적으로 분주하여 $31^{\circ} \mathrm{C}$ 에서 18 시간 진탕배양 (130 rpm)하였다. 병원성 균은 $10^{7} \sim 10^{8} \mathrm{CFU} / \mathrm{mL}$ 의 농도로 접종하였으며 Muller-Hinton broth $1 \mathrm{~mL}$, 미생물 $1 \mathrm{~mL}$ 를 가한 것을 양성 대조구로 사용하고 미생물을 무접종한 배지 를 음성 대조구로 하여 잔존균의 탁도를 육안으로 비교하였 다.

\section{통계처리}

모든 실험 결과는 SPSS(ver. 24, IBM Corp., Armonk, $\mathrm{NY}, \mathrm{USA}$ )를 이용하여 평균과 표준편차로 나타냈으며 Duncan's multiple range test로 $5 \%$ 유의수준에서 수행하였다.

\section{결과 및 고찰}

\section{저장 중 수분함량}

본 실험은 예비실험을 통해 최적의 제조조건으로 결정된 향 캡슐을 제조하여 $45 \mathrm{~g}$ 의 향 캡슐과 $260 \mathrm{~g}$ 의 염화칼슘을 저장 용기에 함께 넣어 상온 $\left(25 \sim 30^{\circ} \mathrm{C}\right)$ 에서 저장실험을 진 행하였다. 저장 용기 내 저장된 향 캡슐의 저장 중 수분함량 은 Table 1 과 같다. 제조 직후(0일경)에 $90.93 \%$ 였던 수분 함량이 10 일경에 $41.71 \%$ 로 급격하게 감소하였고 $(P<0.05)$, 그 후 저장 33 일경까지 $40 \%$ 범위 내외에서 일정수준을 유 지하였다. 이는 저장 중 용기 내의 염화칼슘이 저장 초기에 는 용기 내의 공기 중 수분을 흡수함으로써 감소한 것으로 보이며, 그 후에는 용기 내의 수분함량이 일정량의 평행상태
를 유지하여 이 이상의 수분감소가 일어나지 않은 것으로 사료된다.

\section{저장 중 향기성분 보유율 및 sniffing 강도}

향 캡슐의 저장 중 총 향기성분 함량의 변화는 Table 2 와 같다. 제조 직후(0일경)에서 향기성분의 총 함량은 $32,388.75$ $\mu \mathrm{g} / \mathrm{g}$ 이었으나 저장 10 일경에는 $2,689.42 \mu \mathrm{g} / \mathrm{g}$ 으로 잔존율 이 $8.3 \%$ 로 급격히 감소하였다. 이후 15 일, 28 일 및 33 일경 에 향 함량은 각각 $1,244.79,465.68$ 및 $593.20 \mu \mathrm{g} / \mathrm{g}$ 이었 고, 잔존율은 각각 $3.84,1.44$ 및 $1.83 \%$ 로 28 일차까지 감소 하였다가 33 일경에 오히려 증가하였다. 이는 저장기간 중의 수분함량과 매우 유사한 패턴을 보였는데, 공기 중에서 흡수 한 수분으로 평행상태를 유지한다면 캡슐 내의 핵물질인 향 기성분이 피복물질인 알긴산과 계면활성제인 Tween 60의 가교역할로 인해 향기성분의 휘발이 어느 정도 억제된 것으 로 사료된다(Tari와 Singhal, 2002; Song 등, 2012). 따라 서 33일경의 평행 수분상태가 일정량 증가한 것이 향 보유 율에도 영향을 미쳤을 것으로 추측된다. 그러나 0일경부터 33 일경까지의 향 강도 특성 실험에서는 저장 일수가 증가함 에 따라 향 강도는 계속 감소하였다(Table 3). 향의 sniffing 강도는 캡슐 제조 직후인 0일경에 7.0점에서 저장 15 일경까 지는 상당히 높은 향 강도(6.0점)를 유지하였으나, 저장 20 일경에 4.0점대를 유지한 후 계속해서 감소하여 저장 33일 경에는 2.0점을 나타내었다. 그러나 Table 2의 향 보유율과 비교해보면 $3.76 \%$ 보유율을 가진 저장 20 일경에도 여전히 $57 \%$ 의 sniffing 강도를 유지하고 있었다. 이는 향의 함량보 다도 향기성분 화합물의 역치(threshold)와 특성에 따라 좌 우되는 것으로 추정된다(Czerny 등, 2008; Hill 등, 2013). 상대적으로 낮은 역치를 가지는 $(E)$-cinnamaldehyde(역 치, $0.03 \sim 0.045 \mathrm{ppm})$, linalool(0.17 ppb) 및 linalyl acetate (0.1 ppm)는 낮은 농도에서 사람의 후각 수용체 단백질에

Table 1. Moisture contents of fragrance capsules during storage at room temperature ${ }^{1,2)}$ $(\mathrm{g} / 100 \mathrm{~g})$

\begin{tabular}{ccccccc}
\hline & \multicolumn{5}{c}{ Storage day } \\
\cline { 2 - 7 } & 0 & 10 & 15 & 20 & 28 & 33 \\
\hline Moisture contents & $90.93 \pm 0.14^{\mathrm{b}}$ & $41.71 \pm 0.81^{\mathrm{a}}$ & $40.99 \pm 1.18^{\mathrm{a}}$ & $41.39 \pm 0.91^{\mathrm{a}}$ & $39.95 \pm 0.90^{\mathrm{a}}$ & $40.48 \pm 1.12^{\mathrm{a}}$
\end{tabular}

\footnotetext{
${ }^{1)}$ Samples: $45 \mathrm{~g}$ of mixed fragrance capsules composed alginic acid, Tween 60, and mixed scent (lemonglass : rosemary : lavender : cinnamon, 3:3:3:1 ratio, $\mathrm{v} / \mathrm{v})$ in a plastic container $(740 \mathrm{~mL})$.
}

${ }^{2)}$ Mean \pm SD ( $\left.\mathrm{n}=3\right)$.

Mean values having the different letters $(a, b)$ in a row are significantly different by Duncan's multiple range test $(P<0.05)$.

Table 2. Flavor holding capacity of fragrance capsule during storage at room temperature ${ }^{1)}$

\begin{tabular}{lccccccc}
\hline & \multicolumn{7}{c}{ Storage day } \\
\cline { 2 - 7 } & 0 & 10 & 15 & 20 & 28 & 33 \\
\hline \multirow{2}{*}{ Flavor amount $(\mu \mathrm{g} / \mathrm{g})$} & $32,388.75 \pm$ & $2,689.42 \pm$ & $1,244.79 \pm$ & $1,217.71 \pm$ & $465.68 \pm$ & $593.20 \pm$ \\
& $2,745.89^{\mathrm{a}}$ & $832.35^{\mathrm{b}}$ & $227.79^{\mathrm{b}}$ & $322.34^{\mathrm{b}}$ & $72.20^{\mathrm{b}}$ & $224.66^{\mathrm{b}}$ \\
\hline Retention ratio $(\%)$ & 100 & 8.30 & 3.84 & 3.76 & 1.44 & 1.83 \\
\hline
\end{tabular}

${ }^{1)}$ Storage condition: $45 \mathrm{~g}$ of fragrance capsules composed with alginic acid, Tween 60 , and mixed scent (lemongrass, rosemary, lavender, and cinnamon) plus $260 \mathrm{~g}$ of $\mathrm{CaCl}_{2}$ were packaged in a plastic container $(740 \mathrm{~mL})$ at room temperature $\left(25 \sim 30^{\circ} \mathrm{C}\right)$. Mean values having the different letters $(\mathrm{a}, \mathrm{b})$ in a row are significantly different by Duncan's multiple range test $(P<0.05)$. 
Table 3. Sniffing intensity of fragrance capsule during storage at room temperature ${ }^{1,2)}$

\begin{tabular}{cccccccc}
\hline Storage day & 0 & 5 & 10 & 15 & 20 & 28 & 33 \\
\hline Sniffing intensity & $7.0 \pm 0.0^{\mathrm{a}}$ & $6.0 \pm 0.0^{\mathrm{a}}$ & $6.0 \pm 0.0^{\mathrm{a}}$ & $6.0 \pm 0.0^{\mathrm{a}}$ & $4.0 \pm 0.0^{\mathrm{b}}$ & $3.0 \pm 1.41^{\mathrm{c}}$ & $2.0 \pm 0.0^{\mathrm{d}}$ \\
\hline
\end{tabular}

${ }^{1)}$ Storage condition: $45 \mathrm{~g}$ of fragrance capsules composed with alginic acid, Tween 60, and mixed scent (lemongrass, rosemary, lavender, and cinnamon) plus $260 \mathrm{~g}$ of $\mathrm{CaCl}_{2}$ were packaged in a plastic container $(740 \mathrm{~mL})$ at room temperature $\left(25 \sim 30^{\circ} \mathrm{C}\right)$.

${ }^{2)}$ Lavender oil as a control was given 7-point. Sniffing test was executed 7-point hedonic scale by 4 sniffers.

Mean values having the different letters (a-d) in a row are significantly different by Duncan's multiple range test $(P<0.05)$.

도달할 수 있어 향의 냄새가 강하게 난다고 하였다(Czerny 등, 2008; Hill 등, 2013; Ahmed 등, 1978; Zhang 등, 2020; Padrayuttawat 등, 1997). 특히 (E)-cinnamaldehyde는 매우 낮은 flavor 역치를 가지면서 저장기간 동안 상당량 잔존해 있어 냄새 특성 강도에 지배적인 영향을 미쳤을 것으 로 사료된다(Hill 등, 2013).

\section{저장 중 향기성분의 함량 변화}

Table 4 에서는 휘발성 향기성분의 분석 결과를 나타내었 다. 총 56 개의 휘발성 화합물이 검출 및 동정되었는데, 향료 의 주성분인 terpene 계열의 화합물이 18 종으로 가장 많았 고, terpene alcohol류가 17종, aldehyde류와 ketone류 14 종, ester류 6종 순이었으며 acid에서는 acetic acid가 유일 하게 검출되었다. 제조 직후(0일경)에 ester류의 함량이 가 장 많았고 다음으로 aldehyde류와 ketone류, terpene alcohol류 및 terpene류 순이었다. Ester류에서는 linalyl acetate의 함량이 $10,039.48 \mu \mathrm{g} / \mathrm{g}$ 으로 전체 동정된 향기성 분 중에서도 가장 높았다. 이 화합물은 향긋한 과일향 냄새 를 가지고 있으며 베르가못과 라벤더의 주성분으로 알려져 있다(PubChem, 2021). Aldehyde류와 ketone류에서는 (Z)-citral, (E)-citral, $(E)$-cinnamaldehyde의 함량이 각각 $3,347.88,4,246.77,1,880.33 \mu \mathrm{g} / \mathrm{g}$ 으로 많았는데, (Z)-, (E)-citral은 citrus 계열의 레몬그라스향의 주성분으로 강 한 레몬향을 가지며 항균 효과가 보고되고 있다(Onawunmi, 1989). (E)-Cinnamaldehyde는 시나몬향의 주성분으로 spicy한 계피향을 가진다(Eilerman, 2014). Terpene alcohol류에서는 eucalyptol과 linalool의 함량이 각각 2,267.33 $\mu \mathrm{g} / \mathrm{g}$ 과 4,375.41 $\mu \mathrm{g} / \mathrm{g}$ 으로 많았다. Eucalyptol은 유칼립투
스 오일로부터 나오며 시원한 민트향을 가지고 있고(Herderich 등, 2012) linalool은 citrus, floral 향을 가지고 있으 며(Reisenman 등, 2010), 이들 물질은 향료에도 많이 이용 되는 향이다(Kamatou와 Viljoen, 2008). Terpene류에서 는 camphor isomer가 2,266.45 $\mu \mathrm{g} / \mathrm{g}$ 검출되었고 이 향은 woody, 민트향을 가진다(Weyerstahl, 1994). 한편 Fig. 1 에서는 저장기간에 따른 향 캡슐의 그룹별 향기성분 함량 변화를 나타내었는데 저장기간 10일경에 상당량 휘발하여 $1.83 \sim 3.84 \%$ 의 잔존율을 보였다. Aldehyde와 ketone류 중 의 $(Z)-,(E)$-citral류 및 $(E)$-cinnamaldehyde와 linalool, linalyl acetate 및 camphor isomer 등의 화합물은 저장기 간 중 다른 화합물에 비해 잔존량이 많았으며, 이들 화합물 이 향 강도에도 영향을 미친 것으로 사료된다. 특히 (Z)-, (E)-citral류 및 $(E)$-cinnamaldehyde의 함량은 저장 33일 까지도 가장 많이 잔존하였다.

\section{캡슐 향 성분의 항균성}

허브향 성분의 항균성을 $\mathrm{MIC}$ 법을 이용해 측정한 결과를 Table 5에 나타내었다. 향 성분의 항균력은 식품의 저장 안정 성을 증가시킬 수 있는데(Yoo 등, 2005; Prakash 등, 2018) 이것을 캡슐화시키면 산화환경으로부터 보호되는 효과와 더불어 원하는 농도로 일정하게 방출시킴으로써 시너지 효 과를 낼 수 있다. 캡슐화에 의해 향이 천천히 휘발하면서 항균력도 오랫동안 지속시키는 것이다. 향 농도가 1,000 $\mathrm{ppm}$ 까지는 확실한 항균 효과가 나타났고, $100 \mathrm{ppm}$ 농도일 때는 대조군과 비교해서 균이 일부 증식되어 완전한 균 억제 효과는 없었다(Table 5). (E)-Cinnamaldehyde, eucalyptol 및 $(Z)-,(E)$-citral류의 식중독 병원성 균(Listeria in-

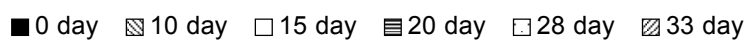

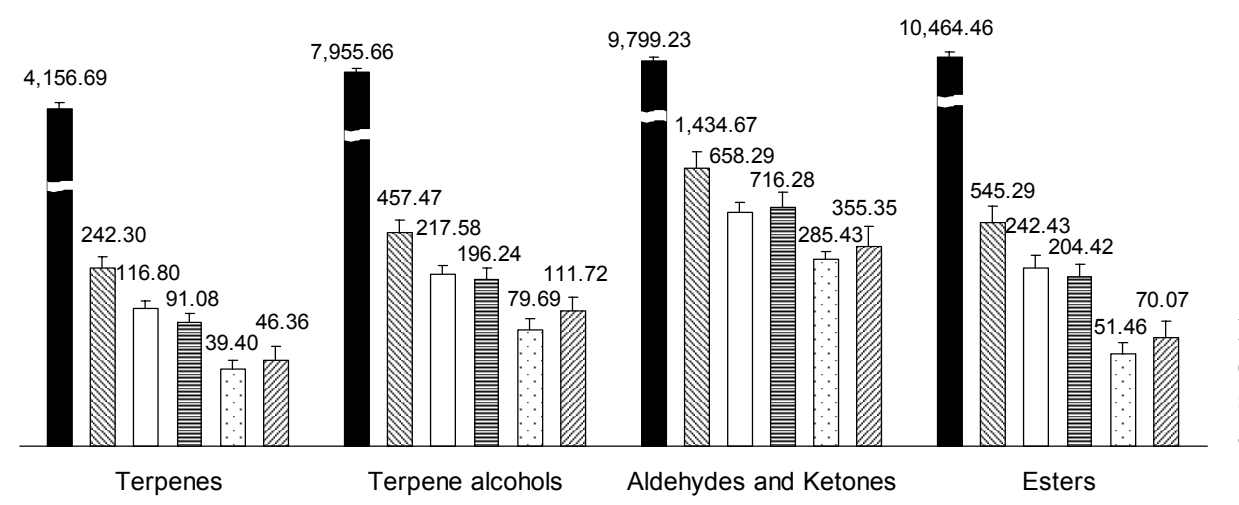

Fig. 1. Mean amounts (ng/g) of group compounds detected in fragrance capsules during storage at room temperature. 


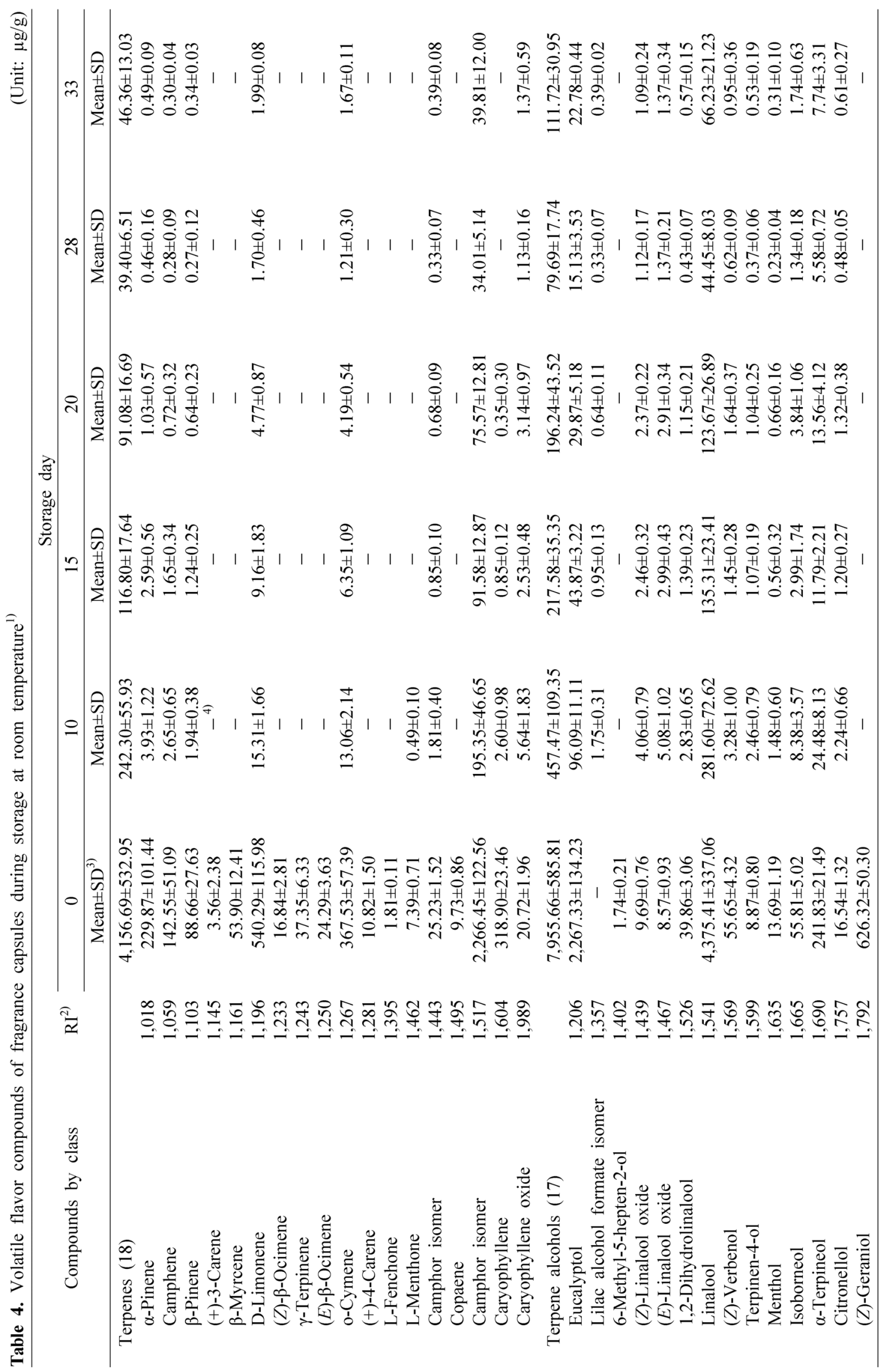




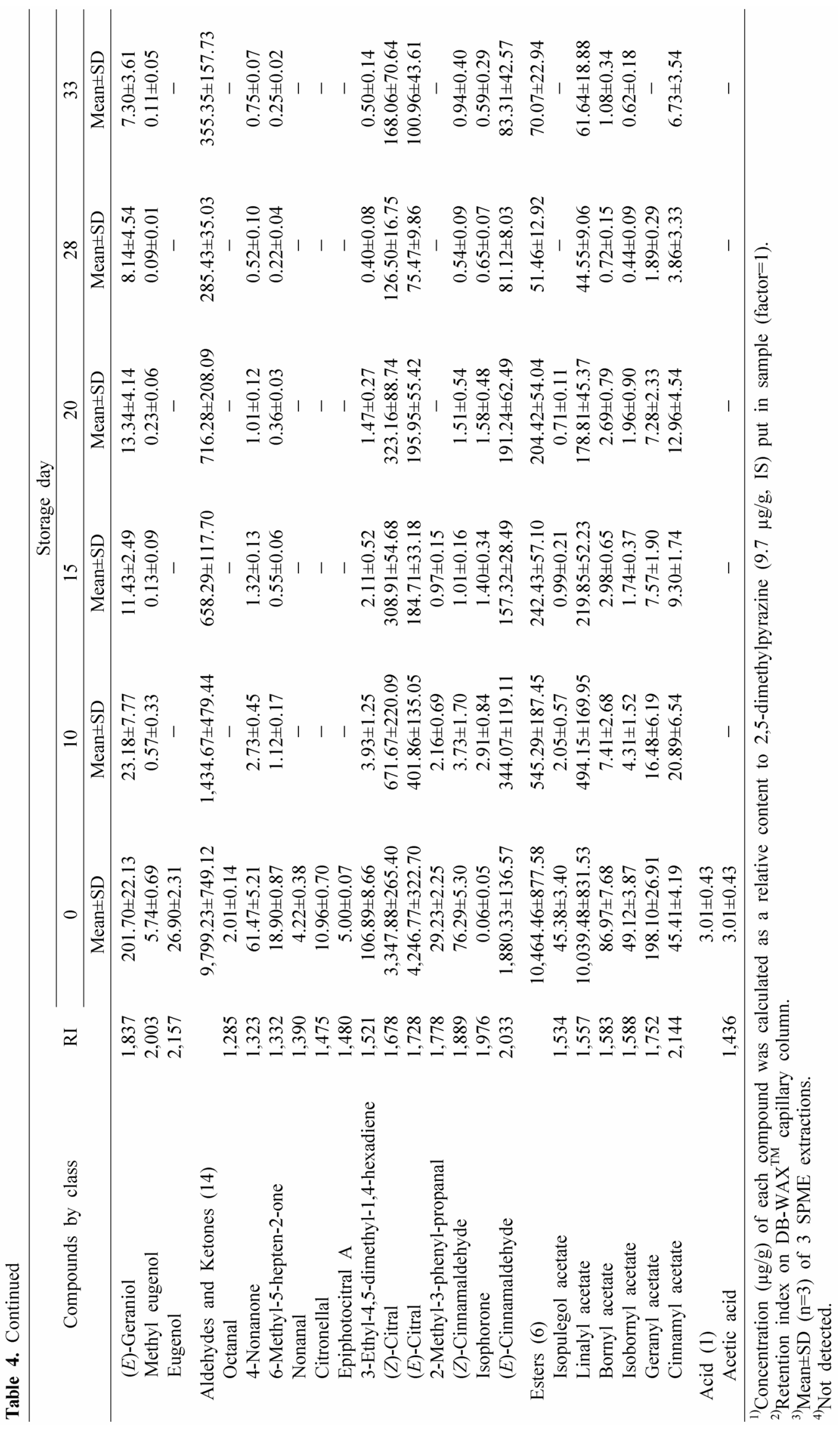


Table 5. MIC of mixed fragrances oil against food pathogenic bacteria

\begin{tabular}{|c|c|c|c|c|}
\hline Conc. $(\mathrm{ppm})^{1)}$ & B. subtilis & E. coli & B. cereus & S. aureus \\
\hline 20,000 & $-{ }^{2)}$ & - & - & - \\
\hline 10,000 & - & - & - & - \\
\hline 5,000 & - & - & - & - \\
\hline 1,000 & - & - & - & - \\
\hline 100 & $\mp^{3)}$ & $\mp$ & $\mp$ & $\mp$ \\
\hline
\end{tabular}

${ }^{1)}$ Mixed fragrance: lemon grass : rosemary : lavender : cinamon $=3: 3: 3: 1$ ratio $(\mathrm{v} / \mathrm{v})$.

${ }^{2)}$ Not detected.

${ }^{3)}$ No growth or a little growth.

nocua, Salmonella Typhimurium)과 진균류(Aspergillus niger, Penicillium sp., Candida albicans)에 대한 항균성 이 각각 400 500 ppm 및 200 512 ppm의 농도에서 보고 되었다(Hill 등, 2013; Matan 등, 2009; Lima 등, 2012). 따라서 본 연구의 향 캡슐 $45 \mathrm{~g}$ 속에 실제로 존재하는 향 농도는 $1,406 \mathrm{ppm}$ 이며, 저장 33일경에도 $500 \mathrm{ppm}$ 보다 많 은 농도 $(593.20 \mathrm{\mu g} / \mathrm{g})$ 로 검출된 것으로 보아 적어도 500 $\mathrm{ppm}$ 이상에서는 항균력이 있을 것으로 추정된다(Table 2). 또한 $1,000 ~ 2,000 \mathrm{ppm}$ 의 범위에서 공시 병원균 4 종에 대 한 항균 효과는 확실히 검증되었기에 저장 20 일경의 농도인 $1,271.71 \mathrm{ppm}$ 에서도 항균 효과가 있을 것으로 사료된다. 그러나 이는 허브향 성분의 직접적인 항균 효과를 알아본 것이고 공중균에 대한 분산향의 항균 효과는 추가적인 실험 이 더 필요할 것으로 사료된다.

\section{요 약}

본 연구에서는 피복물질(wall material)로 알긴산과 Tween 60 을 이용하였고 핵물질(core material)로는 혼합 허브향 (레몬그라스 : 로즈마리 : 라벤더 : 시나몬, 3:3:3:1 비율, $\mathrm{v} / \mathrm{v}$ ) 을 이용해 제조하여 macro 향 캡슐의 향 성분 안정성을 실 험하였다. 향 캡슐의 저장 중 수분함량은 저장기간 동안 28 일까지 점진적으로 감소하였다. 저장 중 향 보유율은 저장기 간에 따라 감소해 10 일경에 급격히 감소하였고 $(P<0.05)$ 그 후 33일경까지 감소한 다음 다시 증가하는 경향을 보인 반 면, 향 캡슐의 sniffing 강도는 저장기간에 따라 감소하기만 하였다. 휘발성 향기성분을 분석한 결과 총 56 종의 화합물 이 동정되었는데, 이는 terpene류(18종), terpene alcohol 류(17종), aldehyde와 ketone류(14종), ester류(6종) 및 acid(1종)로 구성되었다. 이 중 linalyl acetate의 함량이 $10,039.48 \mu \mathrm{g}$ 으로 가장 많았으며, 그다음으로 linalool

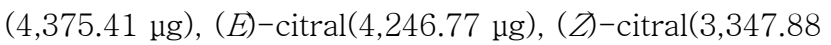
$\mu \mathrm{g})$, eucalyptol(2,267.33 $\mu \mathrm{g})$, camphor isomer(2,266.45 $\mu \mathrm{g}),(E)$-cinnamaldehyde $(1,880.33 \mu \mathrm{g})$ 순이었다. 혼합 향 의 4 가지 미생물에 대한 항균 효과는 향 함량이 $1,000 \mathrm{ppm}$ 이상인 20일경까지는 확실히 검증되었다.

\section{REFERENCES}

Ahmed EM, Dennison RA, Dougherty RH, Shaw PE. Flavor and odor thresholds in water of selected orange juice components. J Agric Food Chem. 1978. 26:187-191.

AOAC. Official methods of analysis. 16th ed. Association of Official Analytical Chemists, Washington, DC, USA. 1996. p 210-219.

Cha SM, Kim GU, Cha JD. Synergistic antimicrobial activity of apigenin against oral pathogens. Int J Eng Res Sci. 2016a. 2:27-37.

Cha YJ, Wang W, Cha HR. Studies on volatile flavor compounds of soy sauce residue. J Korean Soc Food Sci Nutr. 2016b. 45:1755-1761.

Cha YJ. A capsule having antimicrobial and lasting fragrance function and desiccant comprising the same. Korea Patent 102171317. 2020.

Chan ES, Lim TK, Voo WP, Pogaku R, Tey BT, Zhang Z. Effect of formulation of alginate beads on their mechanical behavior and stiffness. Particuology. 2011. 9:228-234.

Cho M, Kim BY, Baik MY, Rhim JH. Microencapsulation of fish oil by low-molecular weight sodium alginate. Korean J Food Sci Technol. 2005. 37:730-735.

Cho YH, Shin DS, Park J. A study on wall materials for flavor encapsulation. Korean J Food Sci Technol. 1999. 31:15631569.

Czerny M, Christlbauer M, Christlbauer M, Fischer A, Granvogl M, Hammer M, et al. Re-investigation on odour thresholds of key food aroma compounds and development of an aroma language based on odour qualities of defined aqueous odorant solutions. Eur Food Res Technol. 2008. 228:265-273.

Eilerman RG. Cinnamic acid, cinnamaldehyde, and cinnamyl alcohol. In: Kirk-Othmer, editor. Encyclopedia of Chemical Technology. John Wiley \& Sons Inc., New York, NY, USA. 2014. p 1-11.

Gibbs BF, Kermasha S, Alli I, Mulligan CN. Encapsulation in the food industry: a review. Int J Food Sci Nutr. 1999. 50: 213-224.

Heinzelmann K, Franke K. Using freezing and drying techniques of emulsions for the microencapsulation of fish oil to improve oxidation stability. Colloids Surf B. 1999. 12:223-229.

Herderich MJ, Siebert TE, Parker M, Capone DL, Jeffery DW, Osidacz P, et al. Spice up your life: analysis of key aroma compounds in Shiraz. In: Qian MC, Shellhammer TH, editors. Flavor chemistry of wine and other alcoholic beverages. American Chemical Society, Washington, DC, USA. 2012. p 3-13.

Hill LE, Gomes C, Taylor TM. Characterization of beta-cyclodextrin inclusion complexes containing essential oils (transcinnamaldehyde, eugenol, cinnamon bark, and clove bud extracts) for antimicrobial delivery applications. LWT - Food Sci Technol. 2013. 51:86-93.

Kamatou GPP, Viljoen AM. Linalool-a review of a biologically active compound of commercial importance. Nat Prod Commun. 2008. 3:1183-1192.

Lai F, Loy G, Manconi M, Manca ML, Fadda AM. Artemisia arborescens L essential oil loaded beads: Preparation and characterization. AAPS PharmSciTech. 2007. 8:E126-E132.

Lee JS, Choi YS, Lee HG. Synergistic antimicrobial properties of nanoencapsulated clove oil and thymol against oral bacteria. Food Sci Biotechnol. 2020. 29:1597-1604.

Lima IO, de Medeiros Nóbrega F, de Oliveira WA, de Oliveire Lima E, Menezes EA, Cunha FA, et al. Anti-Candida albicans effectiveness of citral and investigation of mode of action. 
Pharm Biol. 2012. 50:1536-1541.

Lue KH, Lee SS. The illustrated book of new vegetable. 1st ed. Herbworld Press, Seoul, Korea. 1998. p 239-258.

Marriott NG, Robertson G. Essentials of food safety and sanitation. Chapman \& Hall, New York, NY, USA. 1997. p 46.

Matan N, Woraprayote W, Saengkrajang W, Sirisombat N, Matan N. Durability of rubberwood (Hevea brasiliensis) treated with peppermint oil, eucalyptus oil, and their main components. Int Biodeterior Biodegrad. 2009. 63:621-625.

Onawunmi GO. Evaluation of the antimicrobial activity of citral. Lett Appl Microbiol. 1989. 9:105-108.

Padrayuttawat A, Yoshizawa T, Tamura H, Tokunaga T. Optical isomers and odor thresholds of volatile constituents in Citrus sudachi. Food Sci Technol Int Tokyo. 1997. 3:402-408.

Pei RS, Zhou F, Ji BP, Xu J. Evaluation of combined antibacterial effects of eugenol, cinnamaldehyde, thymol, and carvacrol against E. coli with an improved method. J Food Sci. 2009. 74:M379-M383.

Prakash B, Kujur A, Yadav A, Kumar A, Singh PP, Dubey NK. Nanoencapsulation: An efficient technology to boost the antimicrobial potential of plant essential oils in food system. Food Control. 2018. 89:1-11.

PubChem. National library of medicine (US), national center for biotechnology information; PubChem compound summary for CID 8294, Linalyl acetate. 2021 [cited 2020 Nov 11]. Available from: https://pubchem.ncbi.nlm.nih.gov/compound/ Linalyl-acetate

Reineccius GA. Carbohydrates for flavor encapsulation. Food Technol. 1991. 45:144-147.

Reisenman CE, Riffell JA, Bernays EA, Hildebrand JG. Antagonistic effects of floral scent in an insect-plant interaction.
Proc Biol Sci. 2010. 277:2371-2379.

Soleimanpour S, Sedighinia FS, Afshar AS, Zarif R, Ghazvini K. Antibacterial activity of Tribulus terrestris and its synergistic effect with Capsella bursa-pastoris and Glycyrrhiza glabra against oral pathogens: an in-vitro study. Avicenna J Phytomed. 2015. 5:210-217.

Song S, Wang Z, Qian Y, Zhang L, Luo E. The release rate of curcumin from calcium alginate beads regulated by food emulsifiers. J Agric Food Chem. 2012. 60:4388-4395.

Surh J, Yang HW. Influences of the alginate-calcium ratio and reaction time on the quality of coffee beads prepared by basic spherification. Korean J Food Cook Sci. 2019. 35:159-168.

Tari TA, Singhal RS. Starch based spherical aggregates: reconfirmation of the role of amylose on the stability of a model flavouring compound, vanillin. Carbohydr Polym. 2002. 50: 279-282.

Weyerstahl P. Odor and structure. J Prakt Chem. 1994. 336:95109.

Woo JW, Roh HJ, Park HD, Ji CI, Lee YB, Kim SB. Sphericity optimization of calcium alginate gel beads and the effects of processing conditions on their physical properties. Food Sci Biotechnol. 2007. 16:715-721.

Yong DH, Song M, Yoon HH. Effects of sodium alginate concentration on physical and sensory characteristics of persimmon calcium alginate beads. Korean J Food Cook Sci. 2011. 27:497-505.

Yoo MY, Jung YJ, Yang JY. Antimicrobial activity of herb extracts. J Korean Soc Food Sci Nutr. 2005. 34:1130-1135.

Zhang J, Li J, Wang J, Sun B, Liu Y, Huang M. Characterization of aroma-active compounds in Jasminum sambac concrete by aroma extract dilution analysis and odour activity value. Flavour Fragrance J. 2020. 36:197-206. 